\title{
HUKUM PENGGUNAAN MEDIA SOSIAL BAGI WANITA DALAM MASA IDDAH DAN IHDÂD (PERSPEKTIF QIYÂS)
}

\begin{abstract}
Affan Hatim
Program Magister Hukum Keluarga Pascasarjana UIN Antasari Banjarmasin affan2292@gmail.com

Diterima 06 September 2017 | Direview 23 Juli 2018 | Diterbitkan 01 Oktober 2018

Abstract:

This literature study was conducted by reviewing library materials to find out how Islamic law's perspective on the issue of social media used by women to upload photos featuring beauty in the 'iddah and ibdâd periods. The result of this study showed that the use of social media in the form of uploading photos showing beauty in the period of 'iddah and ibdâd is probibited and not justified by Islamic law. This law of probibition is based on the qiyas argument against the probibition of going out from the house and wearing make up for women in the period of 'iddah and ihdâd. This is because there are similarities' illah, that is the ethics and politeness of the wife by showing grief and mourning over the death of the husband. The qiyas form of this problem is qiyas al-sabr, jaly and aulawy.
\end{abstract}

Keywords: Wanita, Iddah, Ihdâd, Media Sosial dan Qiyâs

\begin{abstract}
Abstrak
Dalam penelitian yang bersifat penelitian normatif atau penelitian kepustakaan ini, dilakukan penelitian dengan meninjau bahan pustaka untuk mengetahui bagaimana menurut hukum Islam tentang masalah penggunaan media sosial oleh wanita dalam 'iddah dan ibdâd dalam bentuk mengunggah foto yang menampilkan kecantikan, dengan melakukan qiyâs ke aktivitas unggah, hingga larangan keluar dari rumah dan berdandan. Hasil dari penelitian bukum ini adalab bahwa penggunaan media sosial dalam bentuk pengunggahan foto yang menunjukkan kecantikan oleh perempuan dalam masa 'iddah dan ibdd dilarang dan tidak dibenarkan dalam bukum Islam. Hukum larangan ini didasarkan pada argumentasi qiyas terhadap larangan keluar dan make up untuk wanita dalam masa 'iddah dan ibdâd karena ada persamaan' illah, yaitu etika dan kesopanan sang istri dengan menunjukkan kesedihan dan berkabung atas kematian sang suami. Bentuk qiyâs dari masalah ini adalah qiyas al-sabr, jaly dan aulawy.
\end{abstract}

Kata Kunci: Wanita, 'Iddah, Ihdâd, Media Sosial dan Qiyâs 


\section{Pendahuluan}

Kemudahan dalam mengakses akun medsos telah membuat medsos tidak bisa dipisahkan dari kehidupan masyarakat. Mereka dapat melakukannya di mana saja, kapan saja, dengan siapa saja, dan tentang apa saja. Medsos telah menjadi backbone (tulang punggung) dalam komunikasi abad digital ini. Akan tetapi selain dampak positif yang ditimbulkan berkat fungsi dan tujuannya, medsos juga memunculkan sisi kelam, menyimpang, dan negatif dari hubungan komunikasi. Medsos yang seharusnya difungsikan untuk tujuan baik, telah dimanfaatkan untuk kepentingan-kepentingan jahat. ${ }^{1}$

Di masa sekarang media sosial telah menjadi gaya hidup dan kegiatan mengunggah foto atau video sudah menjadi kebiasaan yang melekat pada masyarakat modern, hingga melahirkan satu istilah yang dikenal dengan sebutan 'selfie' yaitu mengambil foto diri sendiri baik dilakukan sendirian atau bersama orang lain. Kegiatan menggugah foto dan video sendiri beragam, ada yang sekedar ingin mengganti display picture akun media sosialnya, ada pula yang merekam kegiatan sehari-hari untuk diunggah dan dibagikan kepada orang lain yang ada pada daftar pertemanan. Ketika melakukan 'selfie' atau merekam diri sendiri untuk selanjutnya dibagikan kepada orang lain di dunia maya, tentunya seseorang akan berusaha terlihat dengan penampilan yang menarik.

Kegiatan semacam ini tidak menutup kemungkinan dilakukan oleh perempuan yang masih dalam masa iddah dan ib $\underline{b} d \hat{d}$, mengingat kenyataan bahwa media sosial sudah menjadi bagian kehidupan masyarakat, sementara aturan hukum melarangnya untuk keluar rumah dan merias diri yang bisa menimbulkan ketertarikan orang lain. Ditambah lagi kenyataan bahwa konsekuensi menjadi komunitas maya adalah kebebasan. Kebebasan ini ternyata membawa dampak positif dan negatif bagi penggunanya. Ibarat pisau bermata dua, di satu sisi layanan yang tersedia memberi manfaat besar, di sisi lain bisa menjadi bencana.

Dari sini muncul pertanyaan bagaimana tinjauan hukum Islam terhadap kegiatan seperti tersebut di atas? Apakah kegiatan mengunggah, memajang dan membagikan foto atau video yang menampilkan kecantikan wanita di media sosial dapat diqiyâskan dengan larangan keluar rumah dan merias diri bagi perempuan dalam masa ‘iddah dan ihbdâd yang diatur oleh Islam?

\footnotetext{
1 Tim Pusat Humas Kementrian Perdagangan RI, Panduan Optimalisasi Media Sosial Untuk Kementrian Perdagangan RI, (Jakarta: Pusat Humas Kementrian Perdagangan RI, 2014), h. 43
} 
Untuk mengetahui hukum dari sebuah masalah bisa dengan menggunakan pendakatan ushul fiqih. Dalam kajian ushul fiqib suatu hukum bisa dimunculkan pada kasus hukum baru dengan metode qiyâs. Al-Qiyâs atau lengkapnya, al-qiyas al-tamisili, analogi reasoning, memiliki makna pemikiran analogis terhadap suatu kejadian yang tidak ada ketentuan teksnya, kepada kejadian lain yang sudah ada ketentuan teksnya, lantaran antara keduanya ada persamaan illat hukumnya, serta dengan adanya pertimbangan-pertimbangan untuk kemaslahatan atau kepentingan umum dalam usaha menangkap makna dan semangat dari berbagai ketentuan keagamaan yang dituangkan dalam konsep-konsep tentang istihsân (mencari kebaikan), istishlâh (mencari kemaslahatan). Dalam hal ini, yang dimaksud dengan kemaslahatan adalah kebaikan dan kemanfaatan secara umum (al-mashlabaha al-âmmah, al-mashlabah almursalab). ${ }^{2}$

Pada dasarnya qiyâs tidak menerbitkan hukum (munsyi' al-bukm), qiyâs hanya berfungsi dan berperan dalam mengungkap dan menampakkan suatu hukum (mushbir al-bukm). Hukum sedianya sudah ada pada sumbernya namun belum nampak dan terlihat, maka qiyâs bisa membuatnya nampak dan terlihat melalui perantara íllah. ${ }^{3}$ Sebagai perbandingan, seorang penambang berlian tidak menciptakan berlian yang didapatnya, karena berlian itu sejatinya sudah sejak lama berada dalam tanah, ia hanya menggali tanah tersebut dengan peralatan tambangnya hingga mendapatkan berlian di dalamnya.

Dalam qiyâs, 'illah merupakan dasar utama bagi timbulnya suatu hukum. Tugas seorang mujtabid adalah membuat suatu hukum menjadi nampak berada pada suatu kasus hukum baru/cabang masalah (al-far'u) sebagaimana nampaknya hukum itu ada pada kasus hukum lama/masalah asal (al-ashb). ${ }^{4}$

Dalam masalah penggunaan media sosial oleh wanita dalam masa 'iddah dan $i \underline{h} d a \hat{d}$, penggunaan dimaksud adalah kegiatan mengunggah, memajang dan membagikan foto atau video yang menampilkan kecantikan. Masalah ini merupakan masalah baru (al-far'u) yang perlu diteliti tinjauan hukumnya, salah satu cara untuk mengetahui hukum kegiatan tersebut adalah dengan

\footnotetext{
${ }^{2}$ Lihat, Abdul Wahhab Khallaf, Ilmu Ushûl al-Fiqh, (Kairo: Maktabah al-Da'wah alIslâmiyah, t.t.), h. 52. Lihat Hardi Putra Wirman, "Problematika Pendekatan Analogi (Qiyas) Dalam Penetapan Hukum Islam (Telaah atas Pemikiran Ibn Hazm dan Ibn Qayyim al-Jawziyah)", Asy-Syir'ah 47, No. 1, (2013).

${ }^{3}$ Lihat Wahbah Az-Zuhaili, Al-Wajî̀ fì Ushûl al-Fiqh, (Damaskus: Dar al-Fikr, 2003), h. 56

${ }_{4}^{4}$ Ibid.
} 
menggunakan metode qiyâs. Hal yang paling penting untuk diketahui adalah bagaimana illah yang ada pada masalah ini, dan bagaimana menemukannya hingga bisa dilakukan peninjauan terhadap al-ashl yaitu larangan keluar rumah dan merias diri bagi wanita dalam masa 'iddah dan ihbdâd yang telah diatur dalam hukum Islam.

\section{Metode}

Metode penelitian ini merupakan penelitian normatif atau penelitian kepustakaan ini, dilakukan penelitian dengan meninjau bahan pustaka untuk mengetahui bagaimana menurut hukum Islam tentang masalah penggunaan media sosial oleh wanita dalam 'iddah dan ihdâd dalam bentuk mengunggah foto yang menampilkan kecantikan, dengan melakukan qiyâs ke aktivitas unggah, hingga larangan keluar dari rumah dan berdandan.

\section{Pembahasan}

Tddah berasal kata al-'adad dan merupakan bentuk jamak dari idad. Dalam bahasa arab iddah berarti menghitung (al-ibshba). ${ }^{5}$ Kata ini digunakan untuk maksud 'iddah karena masa itu perempuan yang ber'iddah menunggu berlalunya waktu.

Sedangkan menurut istilah (terminologi) menurut mayoritas ulama adalah masa tunggu bagi seorang perempuan dengan tujuan agar mengetahui kekosongan rahim, atau karena menjalankan perintah agama, atau karena berkabung terhadap suaminya. Kalangan Hanafiyah mengartikan 'iddab dengan masa tertentu yang telah diatur oleh syari'at untuk menghabiskan sisa-sisa dari perkawinan, atau dengan ibarat lain, penantian yang wajib dilalui oleh perempuan ketika putusnya perkawinan atau terjadi syubbat. ${ }^{6}$ Sementara Wahbah al-Zuhaili mendefinisikan 'iddah dengan suatu masa yang telah diatur oleh syâri' setelah terjadi perceraian, di mana pada masa itu perempuan wajib menanti dan tidak boleh menikah hingga berakhir masa tersebut. ${ }^{7}$

5 Wahbah Az-Zuhaili, Al-Fiqh al-Islâmi Wa Adillatubu, cet. 33 (Damaskus: Dar al-Fikr, 2012), h. 591. Lihat Al-Khatib al-Syarbini, Mughnî al-Mubtâj, jilid 3 (Beirut: Dar-alFikr), h. 384

${ }^{6}$ Ibid.

${ }^{7}$ Ibid. 
Kewajiban 'iddah didasari dasar hukum berikut ini, yaitu:

a. Al-Qur'an

Untuk 'iddah akibat talak terdapat pada Q.S. Al-Baqarah/2:228:

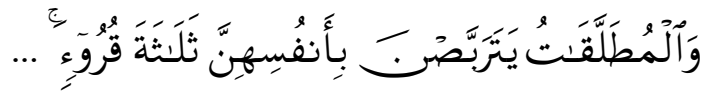

Iddah wafat terdapat pada Q.S. Al-Baqarah/2:234:

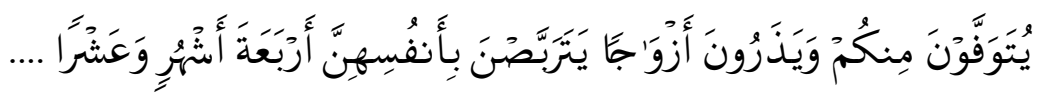

Sedangkan iddah bagi perempuan yang masih kecil dan yang telah berhenti haid dan perempuan yang hamil terdapat dalam Q.S. Al-Thalâq/65:4:

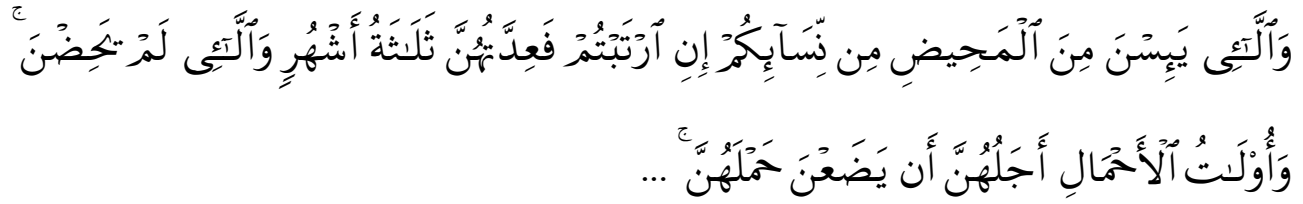

b. Sunnah

Sabda Rasulullah saw. dalam hadits dari Ummu Habibah putri Abu Sufyan: ${ }^{8}$

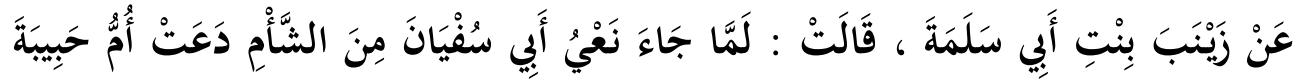

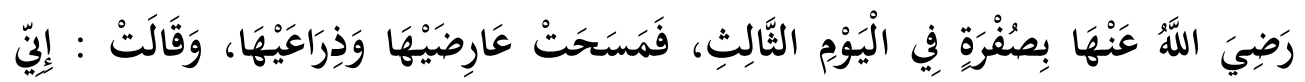

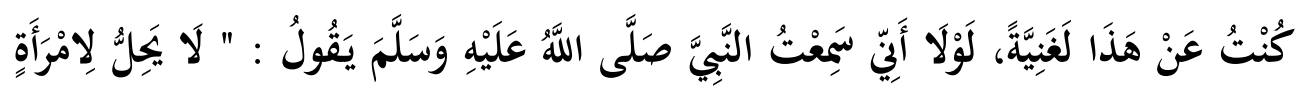

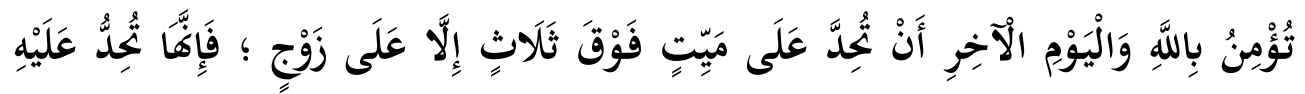

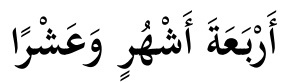

\footnotetext{
${ }^{8}$ Muhammad bin Ismail Al-Bukhori..., h. 303
} 
Secara umum 'iddah menjadi wajib disebabkan salah satu dari dua hal:

a. Perceraian

Iddah menjadi wajib akibat perceraian setelah terjadinya dukhûl baik dari perkawinan yang sah atau tidak sah (seperti perkawinan saudara sesusuan).

b. Kematian Suami

Saat suami wafat maka seketika 'iddah menjadi wajib. Sekalipun antara suami tidak pernah terjadi percampuran. ${ }^{9}$

Iddah terbagi kepada empat macam, yaitu: ${ }^{10}$

a. Tddah dengan hitungan al-aqr ${ }^{\prime}$.

b. Tddah dengan hitungan bulan.

c. Iddah dengan melahirkan anak.

d. Tddah dengan empat bulan sepuluh hari.

Terdapat beberapa larangan-larangan berkaitan dengan masa iddah wafat, yaitu: ${ }^{11}$

a. Melakukan peminangan

b. Melangsungkan perkawinan

c. Keluar rumah

d. Bersolek

Adapun I $\underline{b} d a \hat{d}$ secara bahasa berasal dari kata abadda yang berarti enggan. ${ }^{12}$ Ibnu al-Atsir mengartikannya dengan kesedihan seorang istri atas kematian suaminya dengan memakai pakaian lusuh dan meninggalkan perhiasan. ${ }^{13}$

${ }^{9}$ Ibid., h. 596

${ }_{10}$ Ibid.

${ }^{11}$ Lihat Ibid., h. 618-627. Lihat Al-Khatib al-Syarbini, Mughnî..., h. 395. Lihat Al-Imam Al-Nawawi, Al-Majmû'..., h. 35.

12 Al-Râzy, Mukhtar al-Sihah, (Beirut: Dar al-Kitab al-'Araby, 1967), h. 53. Dalam Iqbal Abdul Aziz al-Muthaww'a, Abkeam al-Tddah wa al-Ihdâd fi al-Figh al-Islami, h. 21.

${ }^{13}$ Lihat Ibnu al-Atsir, Al-Nihâyah fi Gharib al-Hadits wa al-Atsar, jilid 1 (Mesir: Dar Ihya al-Kutub al-Arabiyah t.t.), h. 352. Dalam Iqbal Abdul Aziz al-Muthaww'a, Ahkam alIddah wa al-Ihdâd fi al-Fiqh al-Islami, h. 21. 
Sedangkan pengertian ihbdâd menurut istilah dalam syari'at para fuqahâ mendifinisakannya hampir mirip, yaitu bahwa ih $\underline{i} d \hat{d} d$ adalah meninggalkan riasan dan bersolek dalam masa iddah bagi perempuan yang ditinggal mati oleh suaminya. ${ }^{14}$

Adapun landasan hukum disyari'atkannya ihblâd adalah sebagai berikut:

a. Ayat Al-Qur'an Surat Al-Baqarah/1: 234:

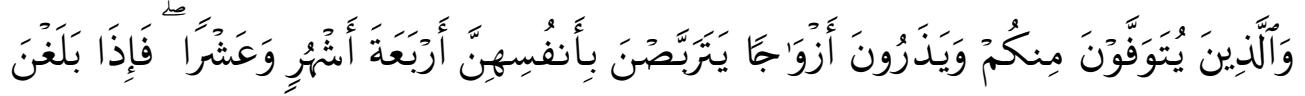

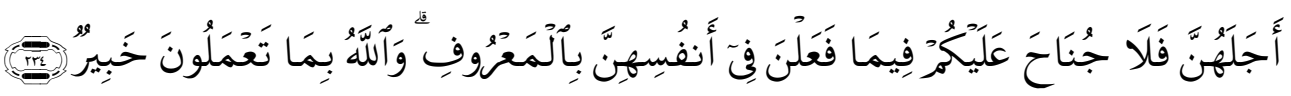

b. Hadits Nabi Muhammad Saw.: ${ }^{15}$

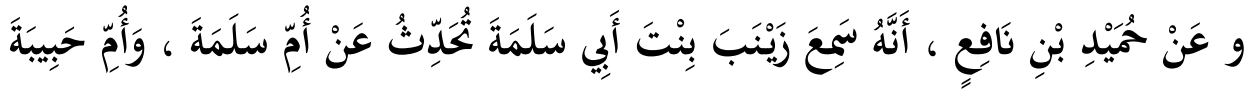

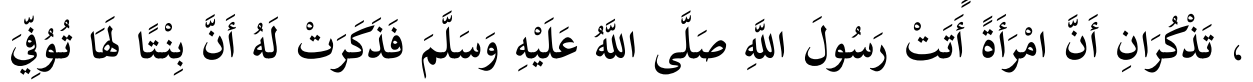

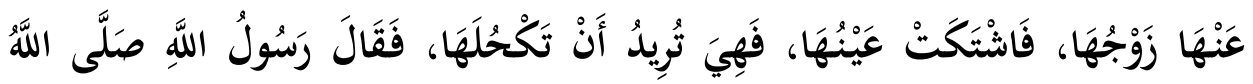

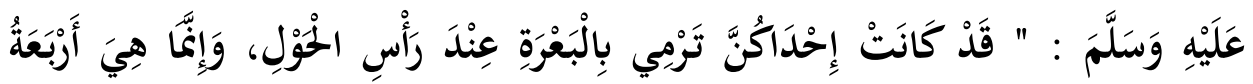
أَشْهُرْ وَعَشْرْ

Hadits dari Ummu Habibah: ${ }^{16}$

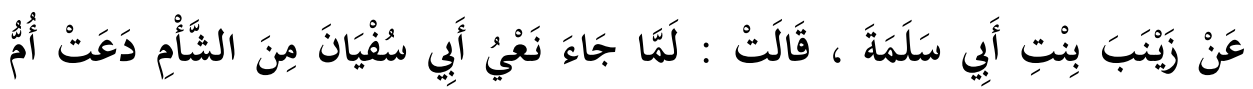

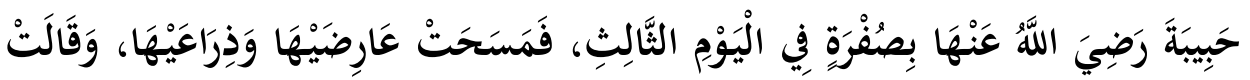

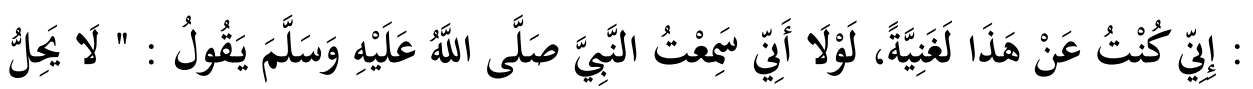

${ }^{14}$ Lihat Iqbal Abdul Aziz al-Muthaww'a, Abkam al-Tddah wa al-Ihdâd fi al-Fiqh al-Islami, (Kuwait: Jami'ah al-Kuwait, 2003), h. 22.

${ }_{15}$ Al-Imam al-Nawawi, Syarh..., h. 94.

${ }^{16}$ Ibid. Muhammad bin Ismail Al-Bukhori, Matan..., h. 78. 


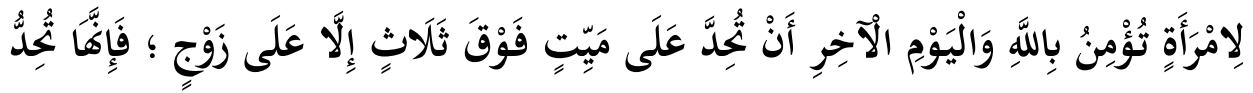

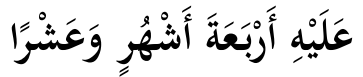

Hadits dari Ummu 'Athiyah: ${ }^{17}$

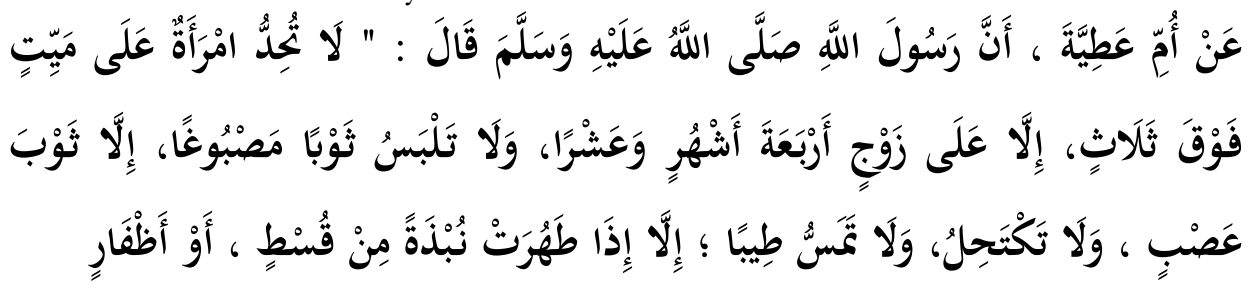

Sedangkan qiyâs secara bahasa dalam istilah lain juga dikenal dengan istilah analogiberarti ukuran, mengetahui ukuran sesuatu, membandingkan atau menyamakan sesuatu dengan yang lain. ${ }^{18}$ Sedangkan secara terminologi, qiyâs memiliki beberapa definisi. Sadr al-Syari'ah tokoh ushul fiqh mazhab Hanafi, mengemukakan pendapat bahwa qiyâs adalah "Memberlakukan hukum asal kepada hukum furü' disebabkan kesatuan 'illah yang tidak dapat dicapai melalui pendekatan bahasa saja." ${ }^{19}$. Sedangkan mayoritas ulama Syafi'iyyah, mendefinisikan qiyâs dengan pengertian "Membawa hukum yang belum diketahui, kepada hukum yang sudah diketahui dalam rangka menetapkan hukum bagi keduanya, atau meniadakan hukum bagi keduanya, baik hukum maupun hukum sifat." ${ }^{20}$ Sementara Wahbah al-Zuhaili mendefinisikan qiyâs dengan "Menyatukan sesuatu yang tidak disebutkan hukumnya dalam nash,

\section{${ }^{17} \mathrm{Ibid}$. h. 96.}

18 Abd Majid Al-Shaghir, al-Fiker al-Ușūly wa Isykâliyyat al-Sulțah al-Imìyyah fì al-Islâm (Beirut: Dar al-Muntakhab al-Arabi, 1994), h. 356. Dalam Hardi Putra Wirman, "Problematika Pendekatan Analogi (Qiyas) Dalam Penetapan Hukum Islam (Telaah atas Pemikiran Ibn Hazm dan Ibn Qayyim al-Jawziyah)", Asy-Syir'ab 47, No. 1, (2013), h. 34 .

${ }_{19}$ Maksudnya, iillah yang ada pada satu nash sama dengan illah yang ada pada kasus yang sedang dihadapi seorang mujtahid. Karena kesatuan 'illab ini, maka hukum kasus yang sedang dihadapi disamakan dengan hukum yang ditentukan oleh nash tersebut. Lihat, Ibid., h. 356.

20 Abu Hamid Muhammad Al-Ghazali, Al-Mustashfa Min Tlmi al-Usbûl, Juz II, (Beirut: Dar al-Kutub al-Ilmiyah, 1983), h. 54. 
dengan sesuatu yang telah disebutkan hukumnya oleh nash, disebabkan adanya kesatuan 'illah antara keduanya". ${ }^{21}$

Dalam proses qiyâs itu, jumhur Ulama menetapkan ada empat hal (rukun) yang harus diperhatikan, yaitu ashl, far'u, 'illah, dan hukum ashl. ${ }^{22}$ Ashl adalah sumber nash yang menerangkan sebuah hukum. Faru' adalah hukum baru yang dikiaskan pada hukum ashl. 'Illah adalah sebab atau hal yang dapat dipersamakan, sedangkan hukum ashl adalah hukum asal yang telah ditetapkan oleh nash.

Qiyâs memiliki empat rukun atau unsur di dalamnya. Berikut ini adalah rukun-rukun qiyâs serta syaratnya masing-masing:

a. Al-Ashl

Al-Ashl adalah kasus induk atau permasalahan asal yang hukumnya telah disebutkan dalam nash ataupun ijm 'a . $^{23}$ Mengenai unsur yang pertama ini, beberapa jumhur ulama menetapkan pula beberapa persyaratan sebagai berikut:

1) Al-ashl tidak mansukh.

2) Hukum syara'.

3) Bukan hukum yang dikecualiakan.

Sebagai misal dari unsur pertama ini ialah, haramnya khamr. Khamr diharamkan berdasarkan firman Allah, sebagaimana terdapat dalam surat al-Ma'idah/5:90:

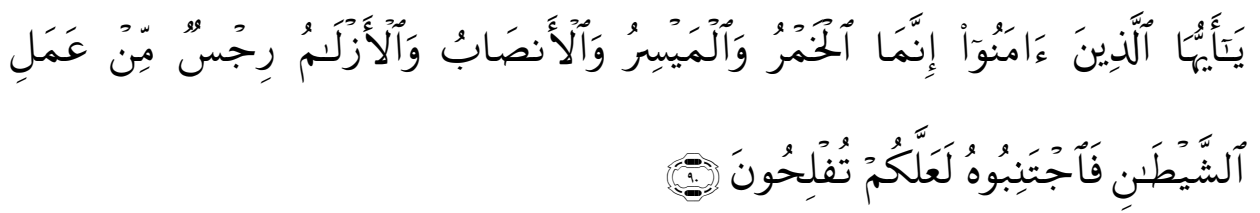

${ }^{21}$ Wahbah al-Zuhaili, al-Wasit fì Ușül al-Fiqh al-Islâmiy (Damaskus: Dar al-Kitab, 1978), h. 601. Dalam Hardi Putra Wirman, "Problematika Pendekatan Analogi (Qiyas) Dalam Penetapan Hukum Islam (Telaah atas Pemikiran Ibn Hazm dan Ibn Qayyim alJawziyah)", Asy-Syir'ab 47, No. 1, (2013), h. 34.

22 Lihat, Muhammad Abu Zahrah, Ushul al-Fiqh (t.p.: Dar al-Fikr al-Arabiy, t.th.), h. 227235-. Dalam Hardi Putra Wirman, "Problematika Pendekatan Analogi (Qiyas) Dalam Penetapan Hukum Islam (Telaah atas Pemikiran Ibn Hazm dan Ibn Qayyim alJawziyah)", Asy-Syir'ah 47, No. 1, (2013), h. 35.

${ }^{23}$ Lihat M. Kholid Afandi dan Nailul Huda, Dari Teori Ushul Menuju Fiqh Ala Tashil Ath-Thuruqat, (Kediri: Santri Salaf Press, 2014), h. 353. Lihat pula Wahbah Az-Zuhaili, Al-Wajiz..., h. 58. 
Keharaman khamr itu dapat menjadi unsur al-ashl untuk menetapkan hukum haram minuman memabukkan lainnya, sebab syarat-syarat alashl telah terpenuhi, yang mana ketentuan haramnya khamr adalah berdasarkan nashsh Al-qur'an, tidak mansukh, ayat tersebut sangat jelas berbicara tentang hukum syara', dan tidak termasuk hukum yang dikecualikan. ${ }^{24}$

b. Al-Far'u

Yaitu permasalahan cabang yang tidak terdapat dalam nash tentang hukumnya dan hendak disamakan dengan permasalahan asal (al-ashb) dalam hukumnya itu. ${ }^{25}$. Terhadap unsur ini, para jumhur ulama menyebutkan beberapa syarat sebagai berikut:

1) Sebelum diqiyâskan tidak pernah ada nash lain yang kemudian menentukan hukumnya.

2) Adanya kesamaan antara 'illah yang terdapat dalam al-ashl dan yang terdapat dalam al-far'u.

3) Tidak terdapat dalil qat'i yang kandungannya berlawanan dengan alfar'u.

4) Hukum yang terdapat dalam al-ashl bersifat sama dengan hukum yang terdapat dalam al-far'u.

c. Hukm al-Ashl

Yaitu hukum permasalahan asal merupakan sebuah hukum syari'at yang disebutkan dalam nash dan hendak dijadikan hukum untuk permasalahan cabang. Terhadap unsur ketiga ini, para jumhur ulama mengatakan, bahwa syarat-syaratnya ialah sebagai berikut:

1) Hukum tersebut adalah hukum syara', bukan yang berkaitan dengan hukum 'aqiliyyat atau 'adiyyat dan atau lughawiyat.

2) 'Illah hukum tersebut dapat ditemukan; bukan saja hukum yang tidak dapat dipahami 'illahnya (ghair ma'qulah al-ma'na).

3) Hukum al-ashl tidak termasuk dalam kelompok yang menjadi khushushiyyah Rasulullah.

24 Dahlan Abd. Rahman, Ushul fiqih h. 163-164. Dalam Mahfudh Fauzi, "Silang Sengkarut Qiyas Dalam Metodologi Hukum Islam”, Hikamuna 1 No. 2, (2016), h. 97. 25 Abdul Wahhab Khallaf, Ijtihad Dalam Syariat Islam, diterjemahkan oleh Rohidin Wahid, (Jakarta: Pustaka Al-Kautsar, 2015), h. 237. 
4) Hukum al-ashl tetap saja berlaku setelah wafatnya Rasulullah; bukan ketentuan hukum yang sudah dibatalkan (mansukh).

Contoh unsur ketiga ini, dikaitkan dengan unsur pertama dan kedua ialah, hukum haramnya khamr. ${ }^{26}$

d. Al-'Tllah

Yaitu suatu sifat yang melandasi hukum permasalahan asal, dan hukum permasalahan cabang disamakan dengan hukum permasalahan asal karena mempunyai 'illah yang sama. ${ }^{27}$ Adapun syarat-syarat 'illah itu sendiri terperinci sebagai berikut :

1) Hendaknya 'illah itu berturut-turut, artinya jika 'illah itu ada maka dengan sendirinya hukumpun ada. Dan sebaliknya apabila hukum ada, maka 'illah pun ada.

2) 'Illah itu jangan menyalahi nash, karena 'illah itu tidak dapat mengalahkannya, maka dengan demikian tentu nash lebih dahulu mengalahkan 'illah. ${ }^{28}$

Para ulama ushul fiqih menyatakan bahwa qiyâs dapat dibagi dari beberapa segi, antara lain sebagai berikut: ${ }^{29}$

a. Dilihat dari kekuatan 'illah yang terdapat dalam furu', dibandingkan dengan yang terdapat pada ashl. Dari segi ini qiyâs dibagi menjadi tiga macam, yaitu; qiyâs al-aulawi, qiyâs al-musawi, qiyâs al-adna.

b. Dari segi kejelasan 'illah yang terdapat pada hukum, qiyâs dibagi kepada dua macam, yaitu; qiyâs al-jaly, dan qiyâs al-khafy.

c. Dilihat dari keserasian 'illah dengan hukum, qiyâs dibagi atas dua bentuk yaitu; qiyâs al-mu'atstsir dan qiyâs al-mula'id.

d. Dilihat dari segi kejelasan atau tidaknya 'illah pada qiyâs tersebut, qiyâs dapat dibagi pada tiga bentuk, yaitu; qiyâs al-ma'na, qiyâs al-'illah, dan qiyâs al-dalalah.

\footnotetext{
${ }^{26}$ Dahlan Abd. Rahman, Ushul..., h. 164. Dalam Mahfudh Fauzi, "Silang..., h. 99.

27 Abdul Wahhab Khallaf, 'Imu..., h. 106

28 Riva'i Muhammad, Ushul fiqih, (Bandung: Alma'arif, t.t.), h. 119. Dalam Mahfudh Fauzi, "Silang Sengkarut Qiyas Dalam Metodologi Hukum Islam”, Hikamuna 1 No. 2, (2016), h. 99.

29 Totok Jumantoro dan Samsul Munir, Kamus Ilmu Ushul Fikih, (Jakarta: Amzah, 2005), h. 273
} 
e. Dilihat dari segi metode (masâlik) dalam menemukan 'illah, qiyâs dapat dibagi; qiyâs al-ikhalah, qiyâs al-syabah, qiyâs al-sabr, dan qiyâs al-thard.

Ulama ushul fiqh berbeda pendapat pada persoalan status kehujjahan qiyâs dalam proses penetapan sebuah hukum syara'. Perbedaan tersebut di antaranya tampak pada pendapat kalangan jumhur ulama yang berpendirian bahwa qiyâs bisa dijadikan sebagai metode atau sarana untuk meng-istinbath-kan semua hukum syara'. ${ }^{30}$ Sedangkan para ulama mu'tazilah berpendapat bahwa qiyâs hanya boleh diterapkan dalam menetapkan sebuah hukum, sepanjang hukum itu dapat memenuhi dua hal. Pertama, selama illah hukumnya manshüsh (disebutkan dalam nash) baik secara nyata maupun melalui isyarat. Kedua, hukum far'u harus lebih utama dari pada hukum ashl. Pada titik ini, Wahbah alZuhaili memetakan pendapat-pendapat ulama ushul fiqh (tentang kehujjahan qiyâs) ke dalam dua kelompok, yaitu kelompok yang menerima qiyâs sebagai dalil hukum, yang terdiri dari mayoritas ulama ushul fiqih seperti ulama Syafi'iyyah, dan kelompok lainnya adalah kelompok yang menolak qiyâs sebagai dalil hukum, yang di antaranya terdiri dari ulama-ulama syi'ah al-Nazzam, Dhahiriyyah, serta ulama mu'tazilah Irak. ${ }^{31}$

Bila ditelaah lebih lanjut, alasan kelompok yang menolak qiyâs sebagai dalil dalam menetapkan hukum syara' di antaranya disandarkan kepada firman Allah dalam surat al-Hujurât/49:1:

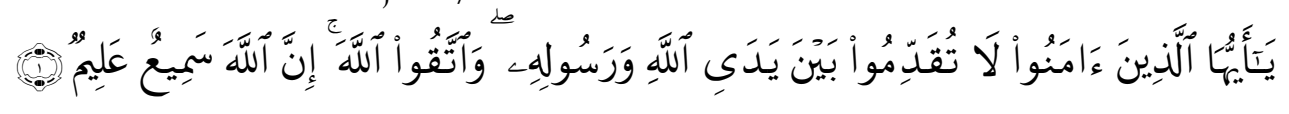

Ayat ini dalam perspektif kelompok tersebut mengandung pengertian adanya larangan bagi seseorang untuk beramal dengan sesuatu yang tidak ada dalam al-Qur'an dan sunah Rasul. Dengan demikian, menurut mereka, menjadikan qiyâs sebagai pedoman merupakan sikap beramal atas dasar sesuatu yang berada di luar al-Qur'an dan sunnah Rasul, dan karenanya dilarang. Selain itu, mereka juga memaparkan isi surat al-Isrâ'/17:36:

30 Tajuddin 'Abdul Wahab al-Subki, Jam'u al-Jawâni' (Beirut: Dar al-Fikr, 1974), h. 177. Lihat juga Ibn Qudamah, Raudah al-Nadkir wa Jannah al-Munadbir (Beirut: Mu'assasah al-Risalah, 1978), h. 234. Dalam Hardi Putra Wirman, "Problematika..., h. 35.

${ }^{31}$ Wahbah al-Zuhaili, al-Wasit..., h. 645. Dalam Hardi Putra Wirman, "Problematika..., h. 36 . 


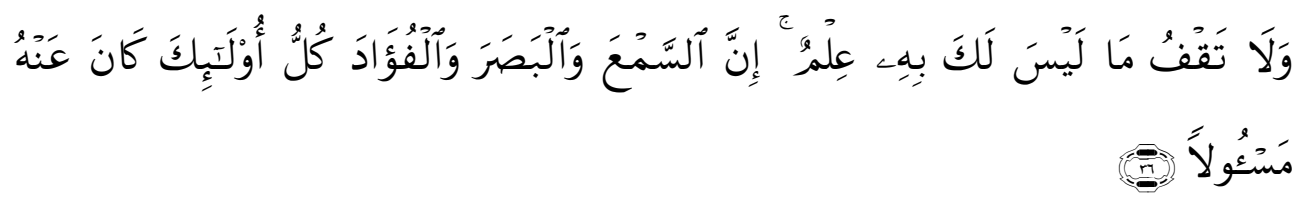

Yang menurut mereka mengandung pengertian bahwa Allah melarang seseorang untuk beramal dengan sesuatu yang tidak diketahui secara pasti (qath'i). Oleh sebab itu, berdasarkan ayat-ayat tersebut, mereka kemudian menyimpulkan bahwa penggunaan qiyâs dalam yurisprudensi Islam adalah sesuatu yang tidak diperbolehkan. ${ }^{32}$

Sedangkan jumhur ulama ushul fiqih yang membolehkan qiyâs sebagai salah satu metode dalam hukum syara', dalam mengemukakan argumentasinya juga disandarkan kepada beberapa ayat al-Qur`an, yang di antaranya adalah Surat al-Hasyr/59:2:
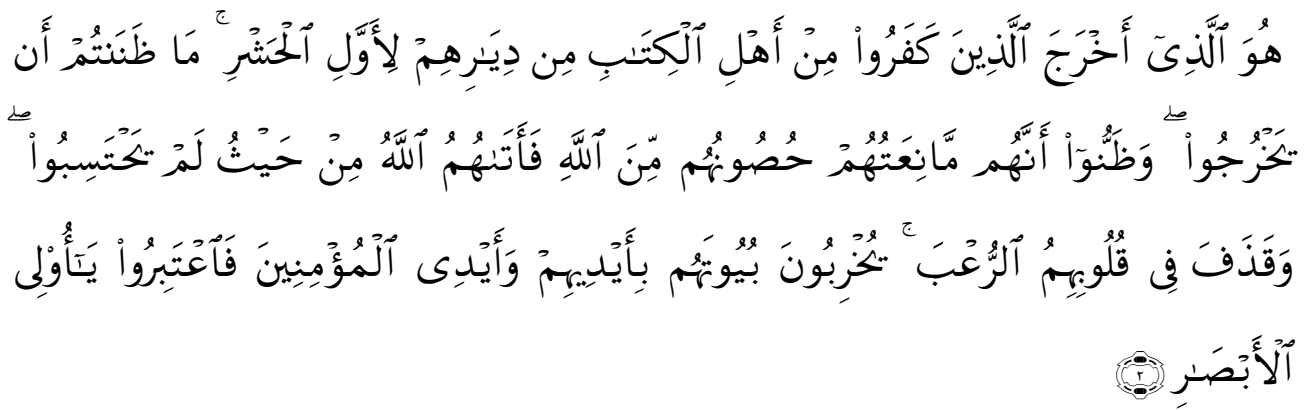

Menurut mereka, ayat tersebut berbicara tentang hukuman yang diturunkan oleh Allah kepada kaum kafir dari Bani Nadhir, sebagai buah atas sikap buruk mereka terhadap Rasulullah. Di akhir ayat tersebut, Allah memerintahkan agar umat Islam menjadikan kisah ini sebagai pelajaran, termasuk dalam kategori qiyâs. Oleh sebab itu, mereka menyimpulkan bahwa penetapan hukum melalui qiyâs yang disebut Allah dengan al-I'tibâr adalah boleh, dan bahkan al-Qur'an telah memerintahkannya. ${ }^{33}$

Ayat-ayat lain yang juga dijadikan oleh mereka sebagai alasan diperbolehkannya qiyâs adalah seluruh ayat al-Qur'an yang mengandung 'illah

${ }^{32}$ Muin Umar, dkk., Ushul Fiqh I Jakarta: Proyek Pembinaan Prasarana dan Sarana Perguruan Tinggi Agama/IAIN, Direktorat Jenderal Pembinaan Kelembagaan Agama Islam Departemen Agama, 1986), h. 116. Dalam Hardi Putra Wirman, "Problematika..., h. 37.

33 Ibid., h. 116. 
sebagai penyebab munculnya hukum tersebut, misalnya Surat alBaqarah/1:222:

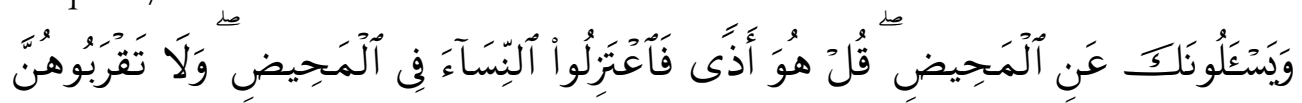

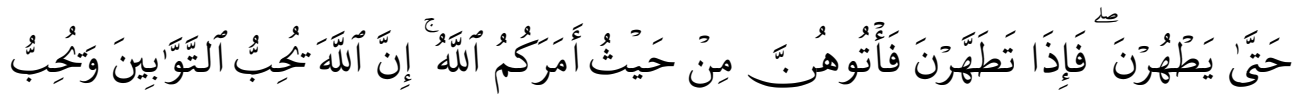

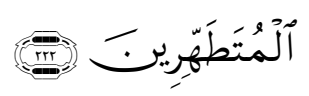

Surat al-Maidah/5:91:

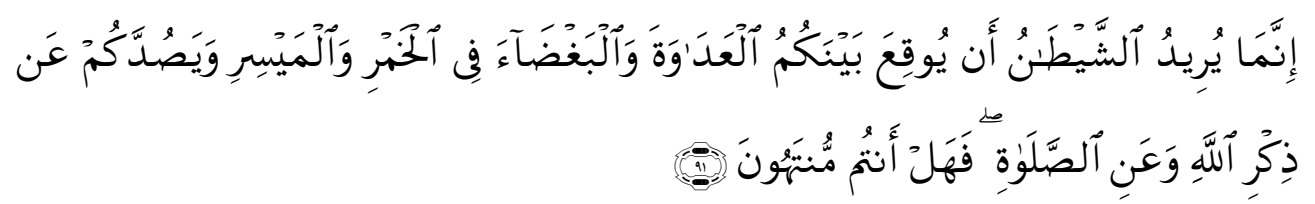

Surat al-Maidah/5:6:

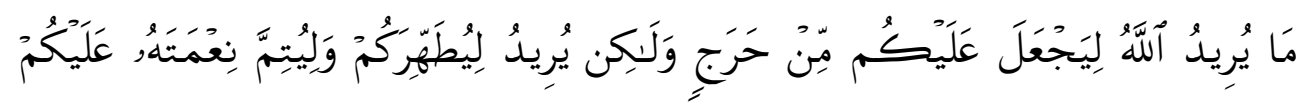

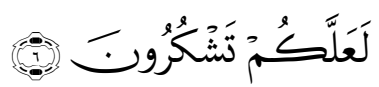

Sebagaimana ulama yang menolak qiyâs, pendapat jumhur ulama yang menerima qiyâs (selain berdasar ayat-ayat al-Qur'an) juga disandarkan atas hadits Rasululah, di antaranya adalah hadits yang diceritakan oleh Muadz Ibn Jabal, yaitu ketika Rasulullah mengutusnya ke Yaman untuk menjadi qadhi. Kala itu Rasulullah melakukan dialog dengan Mu'adz: ${ }^{34}$

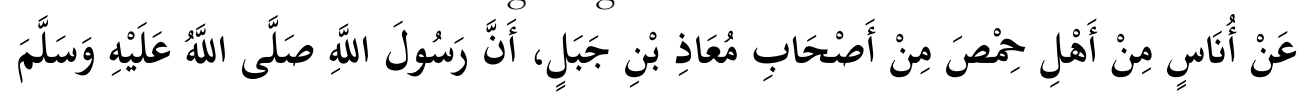

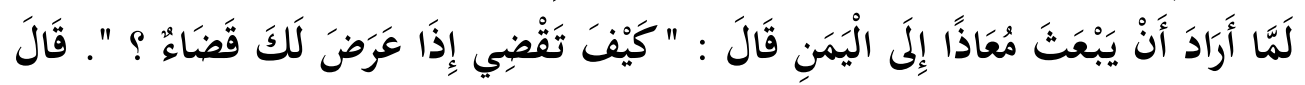

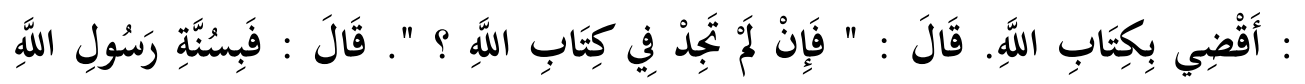

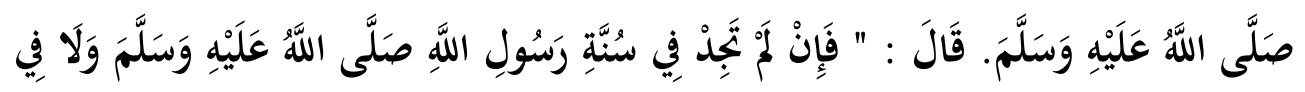

34 Abu Daud al-Sajistani, Sunan Abi Daud, juz 3 (Beirut: Dar al-Fikr, 2003), h. 295. Muhammad bin 'Isa al-Turmudzi, Sunan al-Turmudzi, juz 3 (Beirut: Dar al-Fikr, 2005), h. 62 . 


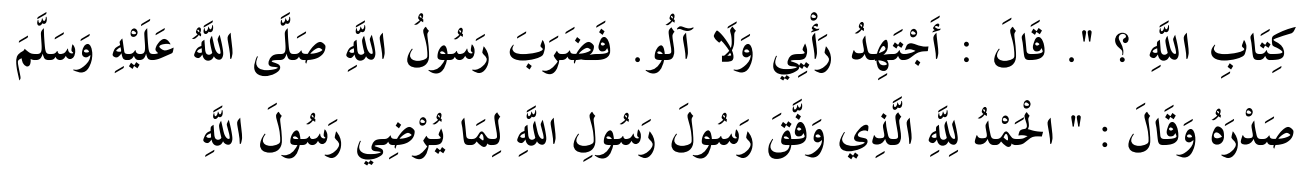

Dalam hadits tersebut, menurut jumhur ulama ushul fiqih, Rasulullah mengakui ijtihâd yang berdasarkan pendapat akal, di mana qiyâs termasuk ijtihad jenis ini. Jumhur tersebut menambahkan bahwa dalam hadits lain, Rasulullah juga menggunakan metode qiyâs dalam menjawab pertanyaan yang diajukan kepadanya. Sebagai contoh, suatu hari Umar bin Khatthab mendatangi Rasulullah seraya berkata: ${ }^{35}$

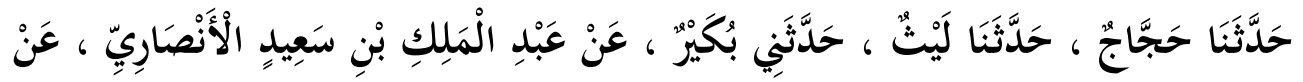

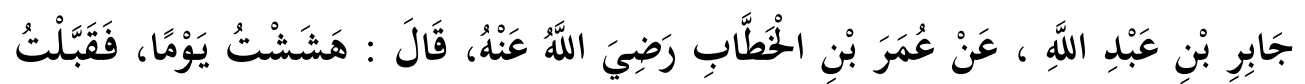

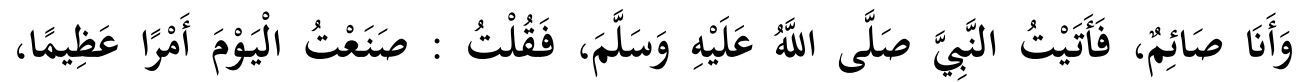

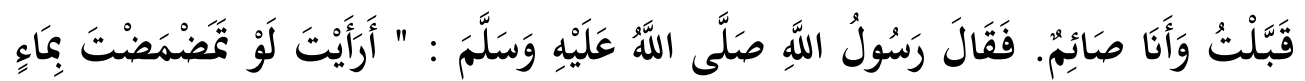

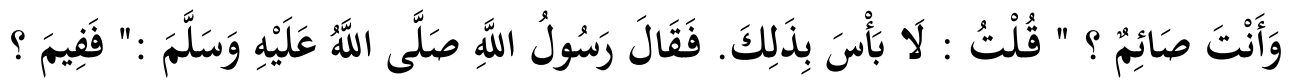

Menurut pendapat jumhur, dalam hadits tersebut, Rasullullah menqiyâskan kumur-kumur dengan mencium istri, yang menurut Rasullullah tidak membatalkan puasa. Dengan demikian, jumhur ulama berpendapat bahwa qiyâs merupakan salah satu metode yang legal dalam proses pencarian sebuah hukum Islam. ${ }^{36}$

\section{Hukum Penggunaan Media Sosial Bagi Wanita Dalam Masa 'Iddah Dan Ihdâd}

Kemudahan dalam mengakses akun medsos telah membuat medsos tidak bisa dipisahkan dari kehidupan masyarakat. Mereka dapat melakukannya di mana saja, kapan saja, dengan siapa saja, dan tentang apa saja. Medsos telah menjadi backbone (tulang punggung) dalam komunikasi abad digital ini. Akan tetapi selain dampak positif yang ditimbulkan berkat fungsi dan tujuannya, medsos juga memunculkan sisi kelam, menyimpang, dan negatif dari hubungan

\footnotetext{
35 Al-Imam Ahmad bin Muhammad bin Hanbal al-Syaibani, Musnad Imam Ahmad, Juz 1 (E-Book Jam'i al-Kutub al-Tis'ah), h. 285.

36 Wahbah Az-Zuhaili, Al-Wajı̂...., 60
} 
komunikasi. Medsos yang seharusnya difungsikan untuk tujuan baik, telah dimanfaatkan untuk kepentingan-kepentingan jahat. ${ }^{37}$

Penulis menemukan beberapa wanita yang sedang menjalani iddah dan ihbdâd menggunakan media sosial dalam akun pribadinya. Penggunaan tersebut berupa mengunggah foto dan video diri mereka dengan penampilan yang menawan, cantik dan menarik. Foto dan video yang mereka unggah dalam akun mereka mendapatkan komentar-komentar bernada rayuan, ketertarikan bahkan sebagian cendrung tidak sopan dari beberapa laki-laki yang melihat postingan mereka. Penulis menghimpun postingan-postingan tersebut dari beberapa media sosial seperti instagram dan facebook.

\section{Instagram}

Penulis menemukan satu akun instagram milik seorang wanita berinisial RE yang berprofesi sebagai seniwati pada bidang seni peran. RE merupakan seorang janda setelah suaminya meninggal pada tanggal 11 Juni 2017. ${ }^{38}$ Setelah kematian suaminya penulis menemukan RE mengunggah foto dirinya pada akun instagram miliknya pada tanggal 30 Juni, 18 Juli dan 24 Juli 2017 dalam foto itu nampak terlihat RE berpenampilan cantik dengan riasan wajah dan busana yang indah, lengkap dengan asesoris penunjang penampilan seorang perempuan. Jika melihat tanggal postingan tersebut dan menghitungnya dengan tanggal kematian suaminya, maka jelaslah bahwa RE masih dalam masa iddah dan ihbdâd. Dalam kolom komentar, penulis menemukan postingan RE tersebut dipenuhi komentar-komentar yang bernada rayuan dan ketertarikan terhadap kecantikan paras RE dari beberapa laki-laki pengguna instagram. Komentar-komentar tersebut di antaranya ada yang berbunyi seperti: "Tante seksi", "You are beautiful woman", "Super duper", "Awesome", "Ko kaya keliatan masih gadis?". Bahkan ada komentar dari seorang wanita pengguna instagram yang mengkritik dan mempertanyakan tindakan RE yang memposting fotonya dengan menampilkan kecantikan dirinya saat sedang dalam masa iddah dan menjalani $i \underline{\not b} d \hat{a} d$, wanita tersebut juga menyebutkan bahwa seorang wanita

${ }^{37}$ Ibid., h. 43

${ }^{38}$ Lihat http:/ / m.liputan6.com. 11 Juni 2017. Diakses pada 26 Juli 2017 
yang ditinggal wafat suaminya wajib berkabung selama empat bulan sepuluh hari sebagaimana disebutkan dalam surat al-Baqarah ayat 234.

\section{Facebook}

Penulis menemukan sebuah akun facebook milik seorang wanita yang akunnya berinisial CH. Perempuan asal Kabupaten Tapin ini memiliki seorang suami yang meninggal dunia pada tanggal 18 Juni 2017 akibat stroke. $^{39}$ Kemudian pada tanggal 15 Agustus 2017, yang berarti ia masih dalam masa iddah dan ihbdâd, CH mengunggah sebuah foto saat berada di suatu tempat. Dalam foto itu $\mathrm{CH}$ terlihat berpenampilan cantik lengkap dengan riasan. Foto yang diunggahnya banyak mendapat like, tanggapan dan komentar dari para pengguna facebook. Salah satu pengguna facebook yang memberikan like dan komentar terhadap unggahanya tesebut adalah seorang laki-laki yang akunnya berinisial MB. Dalam pengamatan penulis MB kerap kali menyukai dan mengomentari foto yang diunggah oleh $\mathrm{CH}$, dan beberapa komentar yang dilontarkannya juga bernada rayuan dan menggoda terhadap CH. Sebagai contoh MB memanggil $\mathrm{CH}$ dalam interaksinya melalui facebook dengan panggilan "adinda", gayung pun seolah bersambut dengan $\mathrm{CH}$ membalas memanggil MB dengan panggilan "kakanda". Di kesempatan lain keduanya juga berinteraksi dengan berbalas komentar dengan saling menggoda satu sama lain, seperti komentar MB yang merayu $\mathrm{CH}$ dengan mengatakan susah mengenali fotonya saat bersama temantemanya karena badannya yang "lamak mungkal"40, selain itu ia juga mengatakan bahwa ia tidak bosan melihat penampilan $\mathrm{CH}$. $\mathrm{CH}$ terlihat senang dengan interaksi tersebut dengan membalas komentar MB dengan candaan dan balik menggoda MB. Selain unggahan itu, dalam pengamatan penulis $\mathrm{CH}$ juga kerap mengunggah foto-foto lain dalam berbagai kesempatan setelah kematian suaminya, yang menarik pada salah satu unggahannya terdapat komentar seorang perempuan dengan akun facebook berinisial BA, perempuan ini mengomentari unggahan $\mathrm{CH}$ dengan memberi nasehat agar $\mathrm{CH}$ berhenti menggunakan facebook dan menyimpan

${ }^{39}$ Kabar kematian suaminya diberitahukan sendiri oleh $\mathrm{CH}$ melalui akun facebooknya.

${ }^{40} \mathrm{MB}$ memuji $\mathrm{CH}$ dengan mengatakan memilki tubuh yang indah. 
ponselnya sementara waktu pasca kematian suaminya dan jangan membagikan perihal kematian suaminya di media sosial. BA juga menasehati $\mathrm{CH}$ untuk cukup curbat kepada Allah.

Untuk menqiyâs permasalahan tersebut maka dilakukan penqiyâsan dengan meninjau unsur-unsur qiyâs. Dalam kajian ushul fiqh penqiyâsan dilakukan dengan meninjau unsur-unsur qiyâs yang empat, maka penulis dalam hal ini akan menjelaskan masing-masing rukun atau unsur qiyâs tersebut:

a. Al-Ashl

Al-Ashl atau kasus induk yang hukumnya telah disebutkan dalam nash ataupun $\ddot{j m} \mathfrak{c}^{\mathrm{a}}{ }^{41}$ merupakan rukun pertama dalam qiyâs, dalam penelitian ini yang menjadi al-ashl adalah keluar rumah dan merias diri bagi wanita dalam masa 'iddah dan i $\underline{h} d a ̂ d$ yang didasari dalil al-Qur'an dan hadits,

b. Al-Far'u

Al-Far'u adalah kasus baru yang tidak ada dalam nash dan akan dicocokkan dengan al-ashl guna mencari hukumnya. ${ }^{42}$ Dalam penelitian ini yang menjadi al-far'u adalah penggunaan media sosial berupa mengunggah foto atau video yang menampilkan kecantikan wanita yang masih dalam masa 'iddah dan i ibdâd.

c. Al-'Tllah

Al-'Ilah adalah motif yang melatarbelakangi lahirnya sebuah hukum, atau 'illah bisa juga disebut sebagai suatu sifat yang ada pada al-ashl yang sifat itu menjadi dasar untuk menetapkan hukum al-ashl serta untuk mengetahui hukum pada al-far'u yang belum ditetapkan hukumnya. Pada dasarnya 'illah kewajiban 'iddah dan ihbdâd tidak ada ditetapkan baik oleh nash al-Qur'an maupun ijma', sehingga untuk menemukannya penulis akan menganalisanya dengan jalan ketiga dalam pencarian 'illah hukum, yaitu dengan jalan penelusuran atau penggalian (istinbatth).

d. Hukm al-Ashl

${ }^{41}$ Lihat M. Kholid Afandi dan Nailul Huda, Dari..., h. 353. Lihat pula Wahbah AzZuhaili, Al-Wajî...., h. 58.

42 Wahbah Az-Zuhaili, Al-Wajįz..., h. 58. 
Hukm al-Ashl adalah hukum yang telah ditetapkan oleh syari'at dalam nash baik al-Qur'an, hadits atau ijm'a. Hukum asal ini yang nantinya akan dicoba untuk dihubungkan dengan kasus hukum baru yang belum ada hukumnya. ${ }^{43} \mathrm{Hukm}$ al-Ashl dalam penelitian ini adalah keharaman keluar rumah dan merias diri bagi wanita dalam masa 'iddah dan i $\underline{b} d a ̂ d$.

Penelusuran yang penulis lakukan dalam mencari illah adalah dengan menggunakan metode al-sabr wa al-taqsim. Yaitu mengumpulkan beberapa alasan-alasan dari sebuah hukum, dalam hal ini hukum 'iddah dan ihbdâd, kemudian menguji satu persatu alasan-alasan tersebut yang mana yang paling layak untuk dijadikan sebagai alasan hukum 'iddah dan $i \underline{i} d a d$ menurut penilaian penulis, dengan tetap berpedoman pada syaratsyarat illab. ${ }^{44}$ Alasan penulis menggunakan metode ini karena penulis menemukan beberapa alasan-alasan bagi hukum iddah dan ihbdâd, sehingga penulis perlu menguji kelayakan alasan-alasan tersebut.

Penulis akan memulai menguji kelayakan alasan pertama yaitu:

a. Menjunjung tinggi perintah Allah

Banyak fuqobâ yang menjadikan alasan ini sebagai illah dari hukum iddah. ${ }^{45}$ Menurut penulis pendapat ini tidak tepat dijadikan sebagai illah karena pada dasarnya segala hukum Allah baik berupa perintah maupun larangan, sejatinya memang untuk menjunjung tinggi perintah Allah. Setiap manusia sebagai subyek hukum harus dengan suka rela menerima, melaksanakan perintah dan menjauhi larangan Allah apapun bentuknya. Terasa sulit melakukan penqiyâsan jika menggunakan pendapat ini sebagai illah hukum, karena pendapat ini akan membuat hukum menjadi sempit tidak dapat dikembangkan. Pendapat ini lebih tepat dikatakan sebagai hikmah karena merupakan tujuan ke depan atau visi dibalik diberlakukanya hukum iddah dan

${ }^{43}$ Lihat Wahbah Az-Zuhaili, Ushûl..., h. 606. Lihat pula Wahbah Az-Zuhaili, Al-Wajîz. ..., h. 58 .

${ }^{44}$ Lihat Wahbah Az-Zuhaili, Al-Wajî..., h. 77.

${ }^{45}$ Lihat Sayyid Abu Bakar bin Muhammad Syatho, Hâsyiah I'ânat al-Thâlibin, cet. I, Juz 4 (Jakarta: Dar Al-Kutub Al-Islamiyah, 2009), h. 37. 
inhdâd, yaitu sebagai wujud kepatuhan kepada Allah. Hal ini juga sesuai dengan firman Allah Q.S. Al-Dzariyat /51:56:

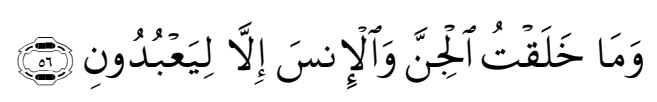

b. Untuk mengetahui dan memastikan kosongnya rahim istri dari embrio suami sebelumnya, agar tidak tercampur dengan embrio lain jika istri menikah lagi.

Harus diakui bahwa terdapat sebagian fuqobâ yang menjadikan tujuan ini sebagai 'illah dari hukum 'iddah. ${ }^{46}$ Pendapat ini menurut penulis juga tidak tepat dijadikan sebagai illah. Karena tidak memenuhi salah satu syarat 'illah, yaitu harus bersifat ta'addy (berkembang, memiliki jangkauan yang jauh)..$^{47}$ Sedangkan pendapat ini bersifat qâshir yaitu bersifat terbatas dan tidak dapat berkembang. Mengapa demikian, karena pada masa sekarang untuk memastikan kekosongan rahim dapat dilakukan dengan cara yang mudah seiring dengan perkembangan teknologi, seperti melakukan tes urine terhadap wanita atau dengan USG (ultrasonography). Jika mempertahankan pendapat ini sebagai 'illah bagi hukum 'iddah, maka konsep ‘ddah sudah tidak relevan lagi untuk zaman sekarang. Oleh karena itu pendapat ini lebih tepat dikatakan sebagai hikmah dari 'iddah.

c. Menjaga kehormatan wanita

Sama halnya dengan poin di atas, alasan ini lebih tepat disebut hikmah ‘ddah dan ihbdâd jika melihat kembali konsep dari hikmah suatu hukum dan perbedaannya dengan illah yaitu bahwa hikmah merupakan tujuan ke depan atau visi dari sebuah hukum. Menjaga kehormatan wanita juga baru dirasa setelah dijalaninya iddah dan ihbdâd. Di mana aturan ‘ddah dan ib $\underline{\text { dâd }}$ melindungi kehormatan wanita agar tidak menjadi objek gunjingan seperti dinilai sebagai "janda centip", atau mendapat rayuan dan olokan orang lain yang melihatnya keluar rumah merias diri setelah berpisah dari suaminya. Agar hal-hal tersebut tidak dialami oleh seorang wanita yang berpisah dari suaminya baik karena

\footnotetext{
46 Lihat Ibid.

${ }^{47}$ Lihat Wahbah Az-Zuhaili, Al-Wajı̂̃..., h. 74, Lihat Wahbah Az-Zuhaili, Ushûl..., h. 656, Lihat Abdul Wahhab Khallaf, Tlmu..., h. 70.
} 
perceraian maupun meninggal, maka syari'at mengatur tentang 'iddah dan $i \underline{b} d a ̂ d$.

d. Mengagungkan dan memuliakan hubungan perkawinan

Alasan ini juga lebih tepat disebut hikmah daripada illah karena baru dirasa setelah menjalani iddah dan ihbdâd. Sebagaimana disebutkan sebelumnya bahwa hikmah merupakan tujuan ke depan atau visi dari sebuah hukum. Dalam hal ini syari'at seolah ingin mengingatkan bahwa perkawinan merupakan ikatan yang sakral dan suci (mitsâqan ghalizha), sehingga ketika hubungan tersebut putus maka harus dilalui lebih dulu masa iddah sebagai bentuk memuliakan hubungan perkawinan dan memenuhi hak suami di dalamnya. Hal ini lebih tepat disebut hikmah karena merupakan proyeksi ke depan dari hukum iddah, yaitu agar manusia tidak berbuat semaunya terhadap perkawinaan, akan tetapi harus memuliakannya dan tidak melupakan hak pasangan.

e. Etika dan kesopanan dengan menunjukkan rasa duka dan berkabung atas kematian suami.

Setelah menganalisa beberapa pendapat di atas dan menemukan bahwa dari poin A hingga D tidak ada yang tepat menjadi illab hukum iddah dan iblâd sekaligus sebagai illah larangan keluar rumah dan merias diri, karena sebagian besar lebih tepat disebut hikmah dan sebagian lainnya tidak memenuhi syarat sebagai illah. Maka penulis menyisakan satu pendapat lagi yang menurut penulis tepat dijadikan sebagai 'illah. Pendapat penulis didasari beberapa alasan, yaitu:

1) Etika dan kesopanan dengan menunjukkan rasa sedih dan berkabung atas kematian suami merupakan alasan yang memenuhi kriteria sebagai illah. Kriteria illah yang penulis maksud yaitu:

a) Kejelasan (al-z̧abir)

b) Menjadi batasan terukur (mundhabith)

c) Dapat berkembang (muta'addi)

d) Sesuai dengan tujuan hukum (munâsib) 
Dengan memperhatikan unsur qiyâs di atas maka jelaslah bahwa larangan keluar rumah dan merias diri bagi wanita yang sedang dalam masa ‘iddah dan ihbâd dikarenakan untuk menjaga etika dan kesopanan istri dengan menunjukkan rasa duka dan berkabung atas kematian suaminya. Etika dan kesopanan merupakan hal yang relevan dijadikan sebagai illah dari hukum iddah dan ib $\underline{\text { ind }}$ sekaligus illah bagi larangan keluar rumah dan merias diri bagi wanita yang menjalani keduanya. Hal ini dikarenakan seorang istri yang berpisah dari suaminya karena meninggal tidak etis dan tidak sopan jika ia langsung keluar rumah di luar keperluannya atau bersolek merias dirinya pasca perpisahan dengan suaminya, seolah tidak ada hubungan perkawinan yang baru dilalui. Dalam sebuah rumah tangga pasti terdapat kenangan yang pernah dilalui oleh sepasang suami istri yang tidak bisa digambarkan oleh orang lain, mereka hidup bersama dalam suka dan duka. Sehingga ketika hubungan perkawinan putus karena satu dan lain sebab, maka jangan sampai perpisahan membuat kenangan tersebut hilang begitu saja. Dalam sebuah perkawinan, diawali dengan sebuah janji kuat serta suci, di mana dua mempelai melakukan perjanjian suci di hadapan Allah, maka tidak benar secara syara, dan dinilai kurang berprikemanusiaan, jika seseorang melupakan perjanjian tersebut. Seolah-olah perempuan tersebut dengan mudah melupakan janjinya terhadap Allah. Seorang perempuan tidak dikatakan menepati janji, jika ia yang baru ditinggal mati suaminya berlebihan dalam berdandan dan mengenakan pakaian mewah yang berbau wangi, perempuan yang langsung berdandan dan bersolek setelah kematian suaminya, terutama di hadapan lawan jenis dipandang kurang etis di masyarakat dan di mata Allah. Untuk itu perlu adanya 'iddah termasuk i ibdâd untuk menghilangkan sisa-sisa dari perkawinan yang telah dilalui dan untuk menghormati hak suami. Dan untuk itu pula seorang istri dilarang keluar rumah dan merias diri selama menjalani masa 'iddah.

Larangan keluar rumah dan merias diri juga berkaitan dengan larangan menikah dan melamar terhadap wanita dalam masa iddah. Allah seolah ingin menutup akses wanita yang sedang dalam iddah dan ịbdâd dari dunia luar sehingga tidak ada orang yang melihatnya agar tidak ada peluang untuk terjadi perkawinan dan pelamaran. Hal ini dimaksudkan agar masa 
¿iddah istri bisa berjalan lancar tidak terganggu dengan laki-laki lain yang ingin menikahinya.

Dengan 'iddah dan ihblâd seorang perempuan menunjukkan ketaatan atas suaminya, sebagaimana ia menjaga etika terhadap suaminya ketika masih hidup, oleh karena itu dapat dipahami bahwa awal mula pensyari'atan ib dâd adalah untuk ta'abbudi, yakni menjalankan syari'at Allah, sehingga bagi siapapun yang melaksanakannya, akan memiliki nilai ibadah di mata Allah dan pasti menimbulkan suatu kemaslahatan serta bentuk rasa hormat seorang perempuan kepada suaminya. Dengan etika kesopanan ini pula menjadi penentu 'iddah bagi seorang wanita yang berpisah dari suaminya dalam keadaan hamil, hikmahnya adalah untuk menghormati benih yang ditanah oleh suami terdahulu. Hal ini juga sesuai dengan hikmah iddah dan ibdâd untuk menjaga kehormatan wanita, yaitu bahwa seorang perempuan yang telah ditinggal mati suaminya, dan kemudian tanpa melaksanakan masa berkabung atau ihdad, seketika beraktifitas seperti biasanya serta bersolek seperti biasanya maka perempuan tersebut, akan menjadi pembicaraan masyarakat, selain juga tidak melakukan syari'at agama.

Dengan demikian, berpegang atas illah hukum iddah dan ihbdâd berupa etika dan kesopanan, maka jika tindakan keluar rumah dan merias diri bagi wanita dalam masa iddah dan ihbdâd merupakan pelanggaran terhadap etika dan kesopanan dengan tidak menujukkan rasa duka dan berkabung terhadap kematian suaminya dan sekaligus melanggar hukum Islam, demikian pula halnya dengan penggunaan media sosial berupa mengunggah foto atau video yang menampilkan kecantikan dan keindahan seorang wanita dalam masa 'iddah dan ihbdâd. Hal ini dikarenakan adanya kecocokan 'illah dari kedua masalah ini.

Sebagaimana telah diketahui pada paparan bahan hukum, terlihat jelas gambaran keadaan penggunaan media sosial oleh wanita dalam masa 'iddah dan ihbdâd, terlihat bagaimana seorang wanita janda ketika mengunggah foto atau video yang menampilkan kecantikan dirinya dalam akun media sosial pribadi miliknya, banyak sekali komentar-komentar dan tanggapantanggapan dari laki-laki di dunia maya yang bernada rayuan dan bahkan cendrung menggunakan kata-kata yang tidak sopan yang merendahkan 
kehormatan seorang wanita khususnya yang berstatus janda. Ditambah lagi kenyataan di masyarakat bahwa seorang janda sangat rentan dengan penilaian negatif dan fitnah yang ditujukan padanya. Selain itu, kesucian, kehormatan dan kemulian sebuah perkawinan juga tidak layak dirusak dengan penggunaan media sosial yang berlebihan dengan menampilkan kecantikan dan keindahan paras seorang wanita.

Dengan penggunaan media sosial seperti itu maka seorang wanita dianggap tidak menjaga etika dan kesopanan di saat suaminya baru saja meninggal, hal ini terbukti dalam paparan bahan hukum dengan adanya beberapa komentar dari pengguna media sosial yang menegur wanita janda yang menggunakan media sosialnya setelah kematian suaminya dan menyuruhnya untuk berhenti untuk sementara menggunakan akun media sosialnya dan cukup mengadu kepada Allah. Hal ini membuktikan bahwa wanita janda yang masih dalam masa 'iddah dan ihbdâd yang menggunakan media sosial dengan mengunggah foto yang menampilkan kecantikanya, dianggap berbuat tindakan yang tidak layak dan tidak pantas. Dengan tindakan tersebut, mengingat media sosial merupakan dunia yang tanpa batas dan terbuka luas bisa dilihat, diakses kapan saja dan oleh siapa saja mereka yang ada di luar sana, akan sangat mungkin bisa menimbulkan fitnah, hal inilah mungkin salah satu yang ingin dihindari sebagaimana disebutkan dalam pasal 170 Kompilasi Hukum Islam. ${ }^{48} \mathrm{Hal}$ itu pula yang mungkin menjadi landasan pemikiran hukum Abdul Muqshit Ghazali tentang doktrin hukum 'iddah dan i ibdâd yang menurutnya ketentuan hukum tersebut haruslah berdasar atas etik-moral. ${ }^{49}$

Oleh karena itu tindakan penggunaan media sosial seperti tersebut merupakan tindakan yang tidak sesuai dengan hukum Islam dan perbuatan yang terlarang. Sebaiknya bagi seorang wanita yang dalam masa iddah dan

\footnotetext{
48 Pasal 170 Kompilasi Hukum Islam:

"Isteri yang ditinggal mati oleh suaminya, wajib melaksanakan masa berkabung selama masa iddah sebagai tanda turut berduka cita dan sekaligus menjaga timbulnya fitnah". 49 Aranni, Amirudin. (ed). Tubuh, Seksualitas, Dan Kedaulatan Perempuan: Bunga Rampai Pemikiran Ulama Muda. (Yogyakarta: LKiS, 2002). Dalam Abdul Helim, "Membaca..., h.287
} 
ihbdâd untuk menjaga etika dan kesopanan, serta menjaga kehormatan dirinya dan suaminya baik di dunia nyata maupun di dunia maya. Larangan ini dimaksudkan untuk menjaga agar tidak terjadi sesuatu yang tidak sesuai hukum syara', karena dalam dunia maya terdapat kebebasan tanpa batas dan tidak ada kontrol.

Dalam teori ushul fiqh tentang qiyâs terdapat beberapa macam qiyâs yang dilihat dari berbagai segi, seperti dari segi kadar kejelasan illah dan kesamarannya, kekuatan 'illah pada hukum dan metode penemuan 'illah. ${ }^{50}$

Pada permasalahan qiyâs penggunaan media sosial oleh wanita dalam masa iddah dan íbdâd, qiyâs yang digunakan jika dilihat dari segi metode penemuan illah termasuk dalam qiyâs al-sabr, yaitu qiyâs yang 'illah di dalamnya ditemukan dengan metode al-sabr wa at-taqsim, yaitu upaya inventarisir beberapa sifat yang nantinya akan dipilih sebagai illah suatu hukum, lalu mengujinya satu persatu hingga ditemukan yang paling layak dan tepat dijadikan sebuah 'illah dengan berpegang pada ketentuan 'illah itu sendiri, sebagaimana pada permasalahan penggunaan media sosial oleh wanita dalam masa 'iddah dan Ibdâd ini, penemuan 'illah dilakukan dengan metode al-sabr wa at-taqsim.

Jika dilihat dari segi kejelasan 'illah pada hukum, maka qiyâs dalam permasalahan ini tergolong sebagai qiyâs jaly dan aulawi, yaitu qiyâs yang mana 'illah di dalamnya jelas dan permasalahan cabang lebih utama dengan hukum yang ditetapkan pada permasalahan asal. Dalam permasalahan penggunaan media sosial pada masa 'iddah dan ihbdâd, yang mana íllabnya adalah untuk menjaga etika dan kesopanan istri dengan menunjukkan rasa duka dan berkabung terhadap suami yang meninggal, perbuatan seorang wanita yang masih dalam masa 'iddah dan iḅdâd menggunakan media sosial dengan mengunggah foto yang menampilkan kecantikan dan bisa dilihat oleh siapa saja, dan mendapat banyak tanggapan dari pengguna media sosial lainnya merupakan sebuah perbuatan yang jelas tidak etis dan sopan jika mengingat akan kematian suaminya, bahkan kadar ketidaksopanan ini lebih besar dibandingkan jika seorang wanita keluar secara fisik dari rumahnya pada saat masa 'iddah, hal ini dikarenakan media sosial menjanjikan kebebasan yang tidak terbatas, bisa dilihat dan diakses kapan saja, di mana saja dan oleh siapa saja. Sehingga tidak etis dan tidak sopan jauh lebih kuat berada pada permasalahan cabang (al-far'u) dibandingkan dengan permasalahan asal (al-

${ }^{50}$ Totok Jumantoro dan Samsul Munir, Kamus..., h. 273 
ashb). Inilah mengapa qiyâs pada permasalahan ini termasuk qiyâs jaly dan aulawy.

\section{Simpulan}

Penelitian ini dapat disimpulkan bahwa Penggunaan media sosial dalam bentuk pengunggahan foto yang menunjukkan kecantikan oleh perempuan dalam masa 'iddah dan ihdd dilarang dan tidak dibenarkan dalam hukum Islam. Hukum larangan ini didasarkan pada argumentasi qiyas terhadap larangan keluar dan make up untuk wanita dalam masa 'iddah dan ihdâd karena ada persamaan' illah, yaitu etika dan kesopanan sang istri dengan menunjukkan kesedihan dan berkabung atas kematian sang suami. Bentuk qiyâs dari masalah ini adalah qiyas al-sabr, jaly dan aulawy.

\section{Daftar Pustaka}

Aranni, Amirudin. (ed). Tubuh, Seksualitas, Dan Kedaulatan Perempuan: Bunga Rampai Pemikiran Ulama Muda. (Yogyakarta: LKiS, 2002). Dalam Abdul Helim, "Membaca Kembali Tllah Doktrin Idah Dalam Perspektif Ushul Al-Fiqh", Karsa, 20, No. 2, (2012)

al-Atsir, Ibnu. Al-Nibâyah fi Gharib al-Hadits wa al-Atsar, jilid 1 (Mesir: Dar Ihya al-Kutub al- Arabiyah t.t.). Dalam Iqbal Abdul Aziz alMuthaww"ea, Abkeam al-Tddah wa al-Ihdâd fi al-Figh al-Islami

Al-Ghazali, Abu Hamid Muhammad. Al-Mustashfa Min Tlmi al-Usbûl, Juz II. Beirut: Dar al- Kutub al-Ilmiyah, 1983.

Huda, M. Kholid Afandi dan Nailul. Dari Teori Ushul Menuju Figh Ala Tashil Ath-Thuruqat. Kediri: Santri Salaf Press, 2014.

Khallaf, Abdul Wahhab. Tlmu Ushûl al-Fiqh. Kairo: Maktabah al-Daeewah alIslâmiyah, t.t.

Khallaf, Abdul Wahhab. Ijtihad Dalam Syariat Islam, diterjemahkan oleh Rohidin Wahid. Jakarta: Pustaka Al-Kautsar, 2015.

Muhammad, Riva ${ }^{e e}$ i. Ushul fiqih, (Bandung: Alma"earif, t.t.),. Dalam Mahfudh Fauzi, "Silang Sengkarut Qiyas Dalam Metodologi Hukum Islam", Hikamuna 1 No. 2, (2016)

Munir, Totok Jumantoro dan Samsul. Kamus Ilmu Ushul Fikih. Jakarta: Amzah, 2005.

al-Muthaww"a, Iqbal Abdul Aziz. Abkam al-Iddah wa al-Ihdâd fi al-Fiqh alIslami. Kuwait: Jamie ah al-Kuwait, 2003. 
al-Nawawi, al-Imam. Al-Majmû' Sarh Al-Mubaddab, cet. 2, juz 22. Beirut: Dar al-Kotob al- Ilmiyah, 2011.

Qudamah, Ibn. Raudah al-Nadkir wa Jannah al-Munadhir (Beirut: Mueassasah al-Risalah, 1978). Dalam Hardi Putra Wirman, "Problematika Pendekatan Analogi (Qiyas) Dalam Penetapan Hukum Islam (Telaah atas Pemikiran Ibn Hazm dan Ibn Qayyim alJawziyah)", Asy-Syir'ab 47, No. 1, (2013)

Rahman, Dahlan Abd. Ushul fiqih. Dalam Mahfudh Fauzi, "Silang Sengkarut Qiyas Dalam Metodologi Hukum Islam”, Hikamuna 1 No. 2, (2016)

Al-Râzy, Mukhtar al-Sihah, (Beirut: Dar al-Kitab al-,Araby, 1967). Dalam Iqbal Abdul Aziz al- Muthawweea, Ahkam al-Iddah wa al-Ihdâd fi al-Fiqh al-Islami

al-Sajistani, Abu Daud. Sunan Abi Daud, juz 3. Beirut: Dar al-Fikr, 2003.

Al-Shaghir, Abd Majid. al-Fiker al-Ușūly wa Isykâliyyat al-Sultah al-Ilmiyyah fi al-Islâm (Beirut: Dar al-Muntakhab al-Arabi, 1994). Dalam Hardi Putra Wirman, "Problematika Pendekatan Analogi (Qiyas) Dalam Penetapan Hukum Islam (Telaah atas Pemikiran Ibn Hazm dan Ibn Qayyim alJawziyah)", Asy-Syir'ab 47, No. 1, (2013)

al-Subki, Tajuddin 'Abdul Wahab, Jam'u al-Jawâni' (Beirut: Dar al-Fikr, 1974) Dalam Hardi Putra Wirman, "Problematika Pendekatan Analogi (Qiyas) Dalam Penetapan Hukum Islam (Telaah atas Pemikiran Ibn Hazm dan Ibn Qayyim al-Jawziyah)", Asy-Syir'ah 47, No. 1, (2013)

al-Syaibani, Al-Imam Ahmad bin Muhammad bin Hanbal. Musnad Imam Ahmad. Juz 1. E-Book Jam'i al-Kutub al-Tis'ah)

al-Syarbini, Al-Khatib. Mughnî al-Mubtâj, jilid 3. Beirut: Dar-al Fikr.

Syatho, Sayyid Abu Bakar bin Muhammad. Hâsyiab I'ânat al-Thâlibin, cet. I, Juz 4. Jakarta: Dar Al-Kutub Al-Islamiyah, 2009.

Tim Pusat Humas Kementrian Perdagangan RI, Panduan Optimalisasi Media Sosial Untuk Kementrian Perdagangan RI, (Jakarta: Pusat Humas Kementrian Perdagangan RI, 2014)

al-Turmudzi, Muhammad bin Isa. Sunan al-Turmudəi, juz 3. Beirut: Dar al-Fikr, 2005.

Umar, Muin, dkk. Ushul Fiqh I (Jakarta: Proyek Pembinaan Prasarana dan Sarana Perguruan Tinggi Agama/IAIN, Direktorat Jenderal Pembinaan Kelembagaan Agama Islam Departemen Agama, 1986). Dalam Hardi Putra Wirman, "Problematika Pendekatan Analogi 
(Qiyas) Dalam Penetapan Hukum Islam (Telaah atas Pemikiran Ibn Hazm dan Ibn Qayyim al-Jawziyah)", Asy-Syir'ah 47, No. 1, (2013)

Wirman, Hardi Putra, "Problematika Pendekatan Analogi (Qiyas) Dalam Penetapan Hukum Islam (Telaah atas Pemikiran Ibn Hazm dan Ibn Qayyim al-Jawziyah)", Asy-Syir'ah 47, No. 1, (2013)

Zahrah, Muhammad Abu. Ushul al-Fiqh (t.p.: Dar al-Fikr al-Arabiy, t.th.). Dalam Hardi Putra Wirman, "Problematika Pendekatan Analogi (Qiyas) Dalam Penetapan Hukum Islam (Telaah atas Pemikiran Ibn Hazm dan Ibn Qayyim al-Jawziyah)", Asy-Syir'ah 47, No. 1, (2013)

az-Zuhaili, Wahbah. al-Wasit fì Ușül al-Fiqh al-Islâmiy (Damaskus: Dar al-Kitab, 1978). Dalam Hardi Putra Wirman, "Problematika Pendekatan Analogi (Qiyas) Dalam Penetapan Hukum Islam (Telaah atas Pemikiran Ibn Hazm dan Ibn Qayyim al-Jawziyah)", Asy-Syir'ah 47, No. 1, (2013)

Az-Zuhaili, Wahbah. Al-Fiqh al-Islâmi Wa Adillatubu, cet. 33. Damaskus: Dar alFikr, 2012.

Az-Zuhaili, Wahbah. Al-Wajı̂̃ fî Ushûl al-Fiqh. Damaskus: Dar al-Fikr, 2003. 